\title{
A Rare Intraorbital Mass: An Isolated Mucocele
}

\section{Nadir Bir Intraorbital Kitle: Izole Bir Mukosel}

\section{Che Mohd Hilmi Che Mat $\odot$, Fakri Mustapha $\odot$, Rosli Mohd Noor $\odot$, Rosdi Ramli $\odot$, Irfan Mohamad $\odot$}

Ethics Committee Approval: Not Applicable.

Conflict of interest: The authors declare that they have no conflict of interest.

Funding: None.

Informed Consent: Informed consent was taken
Cite as: Che Mat CMH, Mustapha F, Noor RM, Ramlı R, Mohamad I. A rare intra-orbital mass: An isolated mucocele. Medeni Med J. 2020;35:344-8.

\begin{abstract}
Mucocele is a mucous filled benign cystic lesion. It develops due to obstruction of any natural ostium of the paranasal sinus. Even though being benign, it has capability to erode and cause thinning the adjacent bony structures. Isolated intraorbital mucocele without paranasal sinus disease is a rare condition. We present a 39-year-old female patient with right medial canthal swelling without any nasal symptoms, and normal nasoendoscopic finding. Imaging revealed the lesion as a right ethmoidal mucocele with normal paranasal sinuses. However intraoperatively, it was an isolated intraorbital lesion, lateral to lamina papyracea with thick-yellowish mucin discharge.
\end{abstract}

Keywords: Congenital, mucocele, surgery, paranasal sinus, endoscopic

Öz

Mukosel, mukus dolu iyi huylu kistik bir lezyondur. Paranazal sinüste herhangi bir doğal ostiyumun tıkanması sonucu gelişir. lyi huylu olmasına rağmen, bitişik kemik yapılarını aşındırma ve inceltme kabiliyetine sahiptir. Paranazal sinüs hastalığı olmayan izole orbital-içi mukoseli nadir bir durumdur. Sağ medial kantus şişliği olan 39 yaşında bir kadın hasta nazal semptomsuz ve normal nazoendoskopi ile sunulmaktadır. Görüntüleme, lezyonu normal paranazal sinüslere sahip sağ etmoidal mukosel olarak göstermiştir. Ancak intraoperatif olarak, kalın sarımsı müsin akıntısı olan, lamina papiracea lateralinde izole bir orbital-içi lezyondur.

Anahtar kelimeler: Konjenital, mukosel, cerrahi, paranazal sinüs, endoskopik
Received: 30 October 2020

Accepted: 30 November 2020 Online First: 25 December 2020

Corresponding Author: I. Mohamad

ORCID: 0000-0001-8572-0514 Universiti Sains Malaysia,

School of Medical Sciences, Department of OtorhinolaryngologyHead and Neck Surgery, Kelantan, Malaysia

irfankb.usm.my

C.M.H. Che Mat

ORCID: 0000-0002-6700-8141 Universiti Sains Malaysia, School of Medical Sciences, Department of Otorhinolaryngology-Head and Neck Surgery, Kelantan, Malaysia

F. Mustapha ORCID: 0000-0003-2790-8126 Hospital Raja Perempuan Zainab 2, Department of OtorhinolaryngologyHead and Neck Surgery, Kelantan, Malaysia

R.M. Noor ORCID: 0000-0002-4423-2765 Hospital Raja Perempuan Zainab 2, Department of OtorhinolaryngologyHead and Neck Surgery, Kelantan, Malaysia

R. Ramli

ORCID: 0000-0001-9605-6065 Hospital Raja Perempuan Zainab 2, Department of OtorhinolaryngologyHead and Neck Surgery, Kelantan, Malaysia 


\section{INTRODUCTION}

Orbital mucocele represents $5 \%$ of all orbital and $30 \%$ of the cystic orbital tumours ${ }^{1}$. It can expand and invade adjacent structures such as the orbital wall or the skull base. Usually, a mucocele develops from obstruction of the normal sinus ostium which leads to formation of a stagnant mucous secretion. Later, this enclosed cystic lesion becomes the nidus for bacterial growth ${ }^{2}$. Secondary infection due to the blocked sinus ostium may lead to orbital cellulitis. Isolated orbital mucoceles without paranasal sinus obstruction is an extremely rare condition.

\section{CASE REPORT}

A 39-year-old female patient without any medical illness presented with right medial canthal swelling persisting for three months. The swelling was painless but gradually increased in size. She also complained of right epiphora and intermittent nasal blockage. There was no blurred vision, history of epistaxis, facial pain, and hyposmia. She also denied any history of trauma or insect bite to the area.

Inspection of the eye demonstrated a solitary rounded lesion at right medial canthus measuring $2 \mathrm{~cm} \times 2 \mathrm{~cm}$ with no overlying skin changes (Figure 1). The mass caused mild right eye proptosis. The mass was non-tender but fixed to the underlying structure. Vision was $6 / 9$ for both eyes. Otherwise, paranasal sinus palpation was normal. Rigid nasoendoscopy only revealed right septal deviation without medialization of the lateral wall of the right nasal cavity (Figure 2). Otherwise, no mass or polyp was seen and the fossa of Rosenmuller were clear.

Computed tomography (CT) scan of orbit and paranasal sinus revealed a well-encapsulated cystic lesion in the right extraconal region measured $2.5 \mathrm{~cm} \times 1.8 \mathrm{~cm} \times 2.3 \mathrm{~cm}$. This lesion caused indentation and convexity of the right lamina pa-

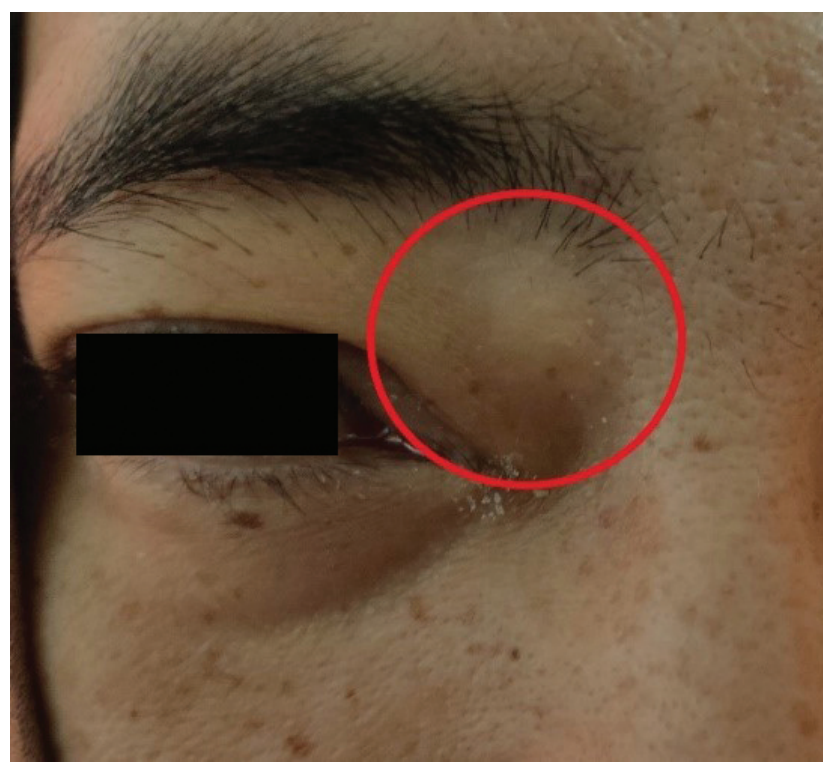

Figure 1. Right medial canthal cystic lesion measuring 2 cm $\times 2$ cm.

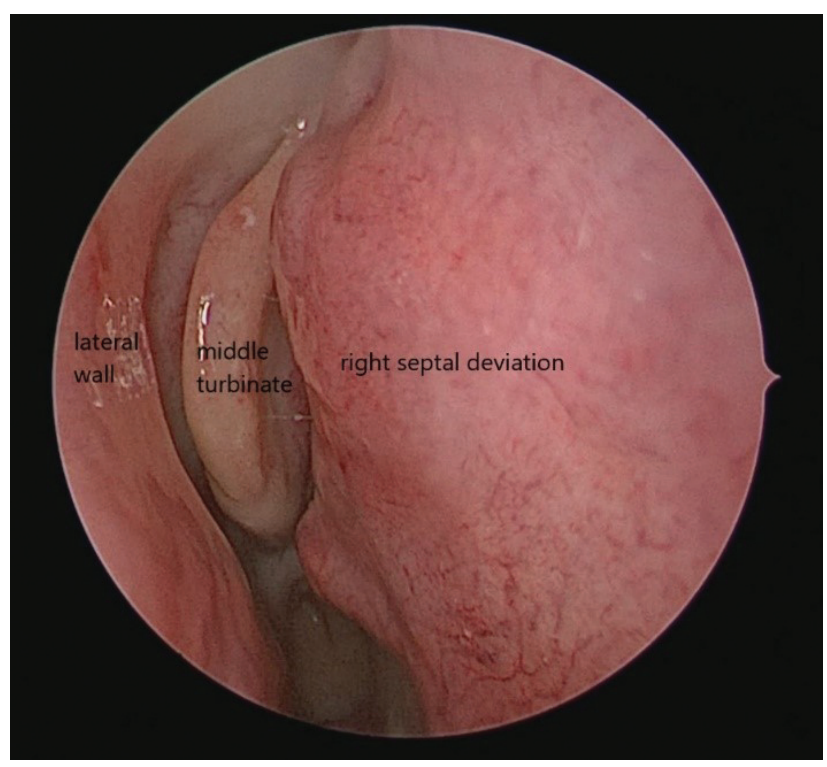

Figure 2. Nasoendoscopy revealed only the right septal deviation.

pyracea (Figure 3). The left lamina papyracea was intact. The wall of the lesion was not thickened or inflamed. No fatty component, calcification, ossification within the lesion were seen. The left lamina papyracea and the orbits were intact bilaterally. Both globes and lenses were normal. The nasal septum deviation to the right side with a small septal spur was detected. The radiological 
diagnosis of orbital dermoid cyst with differential diagnosis from epidermoid cyst was made.

Magnetic resonance imaging (MRI) of paranasal sinuses and orbit revealed an expansile lesion

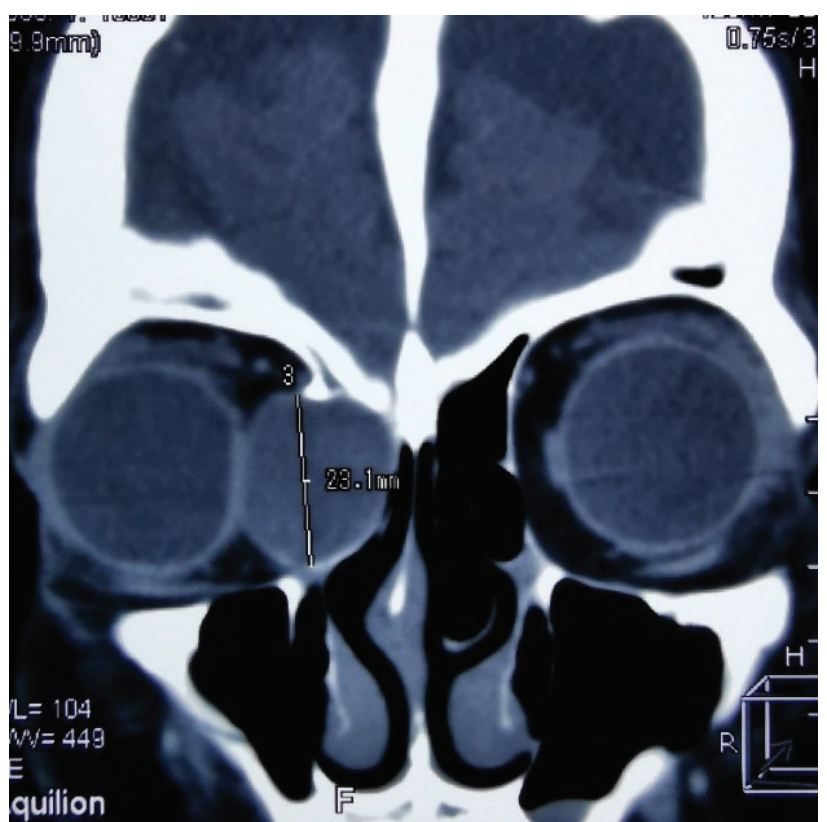

Figure 3. Coronal CT of the orbit revealed a well-defined cyst measuring $2.31 \mathrm{~cm}$ in height lateral to lamina papyracea. Right lamina papyracea splayed towards the nasal cavity.

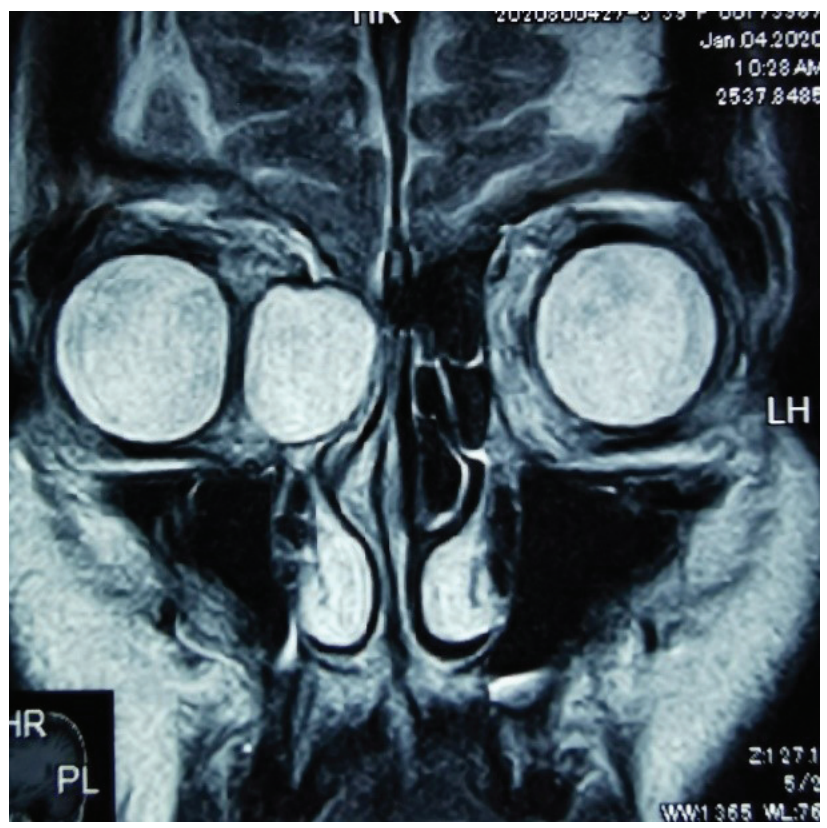

Figure 4. MRI-FLAIR coronal cut revealed a cystic lesion appeared as the third eye. measuring $2.3 \mathrm{~cm} \times 1.5 \mathrm{~cm} \times 2.2 \mathrm{~cm}$. On Fluid Attenuated Inversion Recovery (FLAIR) sequence, the lesion showed hyperintense matrix which caused extrinsic compression of the medial extraconal space of the right orbit appearing as a human with three eyes (Figure 4).

The mass caused complete dehiscence of the anterior part of the right lamina papyracea, compressing the right medial rectus. The right globe was laterally displaced and caused proptosis. Otherwise, the right globe was preserved. The extraocular muscle, the optic nerve, and intraconal fat were preserved. There was no lesion in the region of the right lacrimal gland. Mucosal thickening and polyp were seen in the right maxillary sinus. Mild mucosal hypertrophy in the left anterior ethmoid sinus was identified by MRI as the right ethmoidal mucocele.

Right endoscopic orbital decompression was performed. Then septoplasty was performed to provide surgical access. We thought that the mucocele was originated from right ethmoidal sinus as demonstrated by MRI. However, intraoperatively a retention cyst at posterior ethmoidal sinus with the convexity of lamina papyracea was seen. Mid-

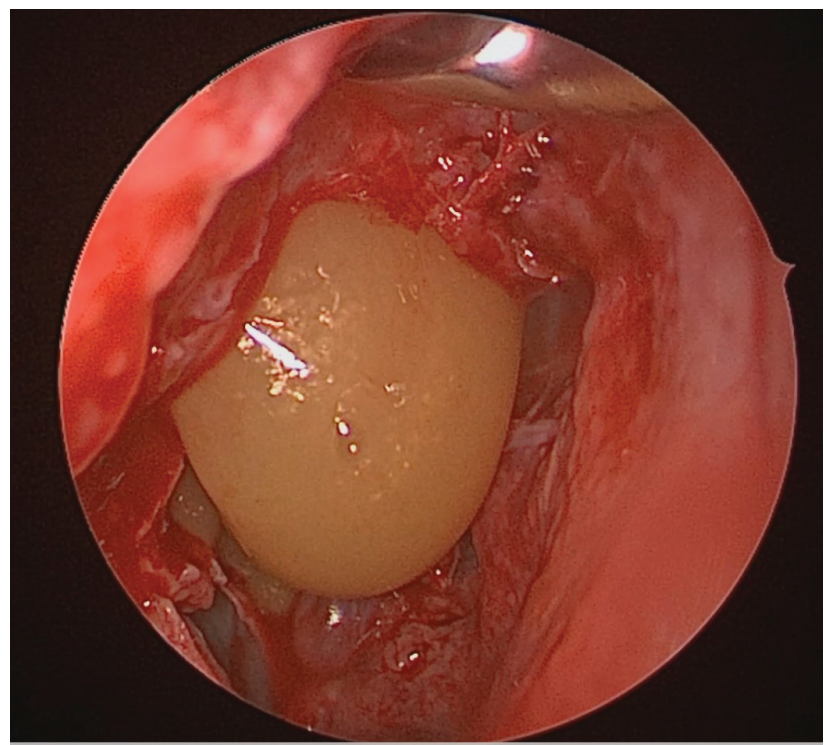

Figure 5. Endoscopic view of post removal of lamina papyracea revealed thick yellowish mucin discharge (mucocele) arose from the orbital cavity. 
dle meatal antrostomy revealed maxillary sinus mucosa looking healthy without any polyp seen. After removal of lamina papyracea thick yellowish mucin discharge (mucocele) coming from the orbital cavity was seen (Figure 5). The fluid drained out was about $10 \mathrm{cc}$ with intact periorbital fat. HPE confirmed that the mass was mucocele.

Postoperatively, none of the complications such as blurring of vision, epistaxis or septal hematoma were seen. Postoperative vision test was $6 / 9$ for both eyes. Upon palpation of right eye postoperatively, any palpable cystic lesion over right medial canthus was not detected. She was discharged well with nasal douching and reviewed a week later on. Rigid nasoendoscopy that was repeated one month after surgery revealed minimal blood clots and absence of synechiae.

\section{DISCUSSION}

Mucoceles are cystic lesions which result from the accumulation of mucous secretions. Mucoceles are lined by pseudostratified columnar epithelium $^{3}$. The primary etiology of mucoceles is blockage of the sinus ostium. The blockage can occur unexpectedly without sinus abnormality or as a result of trauma, surgical injury, tumour invasion, and inflammation.

The symptoms of orbital mucocele depend on the site of origin. The common manifestation of an intraorbital mucoceles is proptosis. It is due to the mass effect to the orbital cavity. The mass effect also causes extraocular muscle restriction which leads to binocular vision, diplopia, and ophthalmoplegia. If mucoceles invade the inferior orbit floor, they will cause lower eyelid distortion, epiphora, medial canthal swelling, and enophthalmos. In the case of orbital mucocele arising from frontoethmoidal sinus, the patient will present with palpable mass at medial canthus and accordingly tend to visit an ophthalmologist in the first place. If orbital mucoceles arise from sphenoidal or posterior ethmoidal sinus, the mass effect can encroach the optic canal and superior orbital fissure, which may cause severe visual loss and paralysis of cranial nerves III, IV and $\mathrm{VI}^{4}$.

However, the orbital mucocele is isolated within the orbit without any communication to the paranasal sinus in our case. Furthermore, the paranasal sinuses in our patient were clear and healthy. The contributing factor for orbital mucocele can be chronic sinusitis, nasal polyp, orbital wall fracture, post open or endoscopic surgery, and congenital effects. It has been postulated that isolated orbital mucocele can occur due to islands of sinus tissue within the orbit that developed from embryological tissue or after trauma ${ }^{5}$. Thus, the island of sinus tissues will proliferate into the cystic lesion within the orbital cavity. As in our case, the patient denied any traumatic injury over the face or orbital area, or postoperative procedure. Thus, the possible etiology in this case could be congenital.

Isolated orbital mucocele has been reported by Baysal et al. ${ }^{5}$. A 55-year-old man was diagnosed with left isolated orbital mucocele without a history of trauma or obstruction of paranasal sinus. Asamoto et al. reported an isolated orbital mucocele from old fracture of 46-year-old man with significant history of minor trauma over the nose happened during ice hockey ${ }^{6}$. He suggested that orbital mucocele was caused by aberration of sinus mucosa into orbital cavity during trauma.

CT scan is a vital tool to detect the location and bony involvement of mucocele. The characteristic image of orbital mucocele is the egg-shell appearance which is described as a space-occupying lesion with surrounding bony erosion? ${ }^{7}$.

In managing the typical sinus-related mucoceles, the patent ostium is needed for sinus ventilation thus facilitating resolution and preventing the recurrence. However, the pathophysiology is different due to the absence of communication with paranasal sinus in isolated congenital orbital mucoceles. The treatment must be complete exci- 
sion and destruction of ectopic sinus tissue within the orbital space. In our case, the cyst wall was excised carefully to remove the entire lesion. Copious water irrigation was done at the surgical site to clear the remnants of mucocele.

In the past, lynch incision was demonstrated to drain the orbital mucocele. However, this technique can cause scaring over the medial canthus, disorientation of medial canthal tendon, and possibility of lacrimal sac injury ${ }^{8}$. Thus, patient may suffer from a late complication like diplopia. Nowadays, most of ophthalmic surgeons perform the transcaruncular approach for orbital mucocele due to wide surgical field ${ }^{9}$. This technique provides more rapid entry into the orbit and less damage to skin and muscle. Furthermore, transcaruncular approach provides better cosmesis with less postoperative scarring.

Endoscopic sinus surgery helps to provide a patent sinus-nasal communication, as most common cause of orbital mucocele is obstruction of natural ostium. Endoscopic sinus surgery will prevent recurrent obstruction of the sinuses and provide the ultimate outflow tract. Furthermore, this approach reduces hospital stay and provide better cosmesis. However, this technique has limitation, if the lesion is lateral to the orbit and in the presence of excessive sclerotic of orbital rim $^{10}$.

\section{CONCLUSION}

Isolated orbital mucoceles in the absence of obstructive paranasal sinus is a rare condition. They mainly occur due to the displacement of island sinus tissue during embryonic period or secondary to trauma which later proliferates into the orbit as a cyst. The radiological assessment is necessary to evaluate the location of the lesion, the potential of old orbital fracture, and the involvement of vital structures. The diagnosis can be made intraoperatively and confirmed with the histopathological assessment. Treatment is mainly surgical removal of the cystic wall and its contents.

\section{REFERENCES}

1. Bonavolontà $G$, Strianese $D$, Grassi $P$, et al. An analysis of 2,480 space-occupying lesions of the orbit from 1976 to 2011. Ophthalmic Plast Reconstr Surg. 2013;29:79-86. [CrossRef]

2. Tailor R, Obi E, Burns J, Sampath R, Durrani OM, Ford R. Fronto-orbital mucocele and orbital involvement in occult obstructive frontal sinus disease. $\mathrm{Br} \mathrm{J}$ Ophthalmol. 2016;100:525-30. [CrossRef]

3. Johnson LN, Krohel GB, Yeon EB, Parnes SM. Sinus tumors invading the orbit. Ophthalmology. 1984;91:209-17. [CrossRef]

4. Hejazi N, Witzmann A, Hassler W. Ocular manifestations of sphenoid mucoceles. Surg Neurol. 2001;56:338-43. [CrossRef]

5. Baysal E, Mumbuç S, Kanlikama M. Intraorbital isolated mucocele. J Craniofac Surg. 2011; 22:754-5. [CrossRef]

6. Asamoto S, Böker DK, Lücke M. Intraorbital mucocele associated with old minor trauma-case report. Neurologia Medico-Chirurgica. 2003;43:383-5. [CrossRef]

7. Curtin HD, Rabinov JD. Extension to the orbit from paraorbital disease. The sinuses. Radiol Clin North Am. 1998;36:1201-13. [CrossRef]

8. Balch KC, Goldberg RA, Green JP. The transcaruncular approach to the medial orbit and ethmoid sinus. A cosmetically superior option to the cutaneous (Lynch) incision. Facial Plast Surg Clin North Am. 1998;87:71-7.

9. Lai PC, Liao SL, Jou JR. Transcaruncular orbitotomy : A new approach to the medial wall. J Tzu Chi Med. 2001;13:211-6.

10. Valerie JL. Endoscopic management of paranasal sinus mucoceles. J Laryngol Otol. 1998;112:36-40. [CrossRef] 